\title{
Innovative Spaces at School. How Innovative Spaces and the Learning Environment Condition the Transformation of Teaching
}

\author{
Giovanni Nulli, Gianluigi Mondaini, and Maddalena Ferretti
}

\begin{abstract}
This paper introduces the contributions to Track C1 of the symposium, which explored the link between architectural space and learning processes, while trying to outline their connection and mutual influence. The paper also aims to outline major trends and innovative approaches in the field of school design. Specifically, it refers to the relationship between the architecture of school, the users' spatial perception, and the capacity to increase learning skills through the experience of comfort and quality spaces. Also, the relationship with the urban structure is investigated as a crucial aspect of school architecture.
\end{abstract}

Keywords School design · Innovative spaces • Learning environments - Spatial experience $\cdot$ Architecture and city $\cdot$ Architecture and pedagogy

\section{Introduction}

The assumption that space works as a "third teacher" addresses the importance of the learning environment in contemporary pedagogy, highlighting how space can contribute to the learning process.

Malaguzzi (in Edwards et al. 2012), the founder of Reggio Children, used the words "third teacher" because of the importance of furnishing a space for a particular purpose, and the importance of having someone with an artistic background to design it. This professional should work with teachers to create a pedagogically oriented space.

\section{G. Nulli (凶)}

Istituto Nazionale Documentazione Innovazione Ricerca Educativa (INDIRE), Florence, Italy e-mail: g.nulli@indire.it

G. Mondaini · M. Ferretti

Department of Civil and Building Engineering, and Architecture (DICEA), Università Politecnica delle Marche, Ancona, Italy

e-mail: g.mondaini@univpm.it

M. Ferretti

e-mail:m.ferretti@univpm.it

D. Scaradozzi et al. (eds.), Makers at School, Educational Robotics and Innovative

Learning Environments, Lecture Notes in Networks and Systems 240,

https://doi.org/10.1007/978-3-030-77040-2_4 
In the National Curriculum Guidelines (Italian Ministry of Education, University and Research, 2012), the Italian curriculum for primary and lower secondary schools has different sections focused on the importance of the learning environment and how it can promote awareness in self-learning, learning by doing, collaboration and the acquisition of a scientific method.

Active pedagogy is based on the previous statement, as both Malaguzzi and the National Curriculum Guidelines have in mind a student who is free to move, experiment, and able to try out his ideas with the teacher's support.

What kind of impact does this pedagogy have on the design of a space?

Building new schools is a long and expensive process, in which different aspects converge: laws, lack of models, decision-makers who know nothing about either pedagogy or architecture. Finally, not many new schools are built every year. It can be hard to design a new school from scratch. The process should be a collaboration between motivated decision-makers, a well-informed school head, and a wellintentioned local community working together to find an architect who is willing to design alongside a pedagogy expert.

There are also increasing cases of schools reimagining old classrooms and existing buildings, in which the first step is producing a pedagogic idea that will be the starting point for designing the space. Classrooms can be clustered together and feature specialist corners, hallways (usually very large), and old labs, closet or storage rooms can be opened up to become larger spaces where students can take part in teamwork, experiential learning and be freer to move.

\section{The Topic: A Dialogue Between Architecture and Pedagogy}

The main theme that Track $\mathrm{C} 1$ tackles is the relationship between architecture and education, especially the positive effect the quality of designed spaces has on the learning experience.

Designing a school building today means experimenting with new models of space that rethink the type of building we became accustomed to, at least in Italy, between the Second World War and the end of the twentieth century. The space will no longer be created by walls alone, that is, a connecting system and repeatable modules in the "classroom cell", but also by the people who animate, interpret and modify it with their presence and creativity in the didactic process. The beauty and empathic attractiveness of the school environment must return to being the center of focus, as an integral and inseparable part of the educational process; it must be a priority for those who design schools, a vision where the inhabitants of the building come first, and the perspective of the dwelling takes precedence over that of the building (Ingold 2000). A new idea of school is pursued that interprets the current needs of teachers and students and, with the quality of its spaces, is able to adhere to contemporary teaching and learning models. 
The principal aspect that is foundational to the architecture of the educational space of tomorrow is its open dimension. School can no longer be rigid, featuring the traditional classroom-corridor model; instead it must consist of dynamic spaces that are both useful and stimulating, and can adapt and engage physically and empathically with those who live and work there.

The definition of new spatial models is certainly conditional on a dialog between architecture and pedagogy and the possibilities offered by new technologies. Today's pedagogy increasingly emphasizes action as the foundation of learning. "Learning by doing" must become the slogan that informs every new project, imagining active settings in the relationship between space and the user. There is a growing move away from the abstract approach to knowledge in favor of personalized, multi-perspective learning (Attia and Weyland 2016).

Architecture should therefore offer a radical shift in the typological flattening of the past, in favor of multi-functional, dynamic and fluid open spaces, experimenting with new conditions of transparency and multi-sensory space for education. The design of physical spaces acts as a strategic tool for updating learning environments and for mobilizing a significant capacity for growing motivated learners and creative problem solvers (Bosch 2018).

\section{Trends and Perspectives}

In Northern Europe, in particular, we find avant-garde schools, where the traditional classroom concept has been superseded by open-space learning environments, with integrated ad hoc furniture solutions that bring students and teachers together, in a way that supports the contemporary pedagogical needs we have outlined. We also find creative interior architectures, real "learning landscapes" formed by open, multifunctional spaces. In addition to offering physical and psychological well-being, welcoming open spaces have a positive effect on learning processes, and contribute to establishing a spirit of community between children and teachers and developing social awareness.

In the Italian context, in recent years, we have also seen a change in the design of training spaces, which, finally, is evidence of a cultural shift. Architecture is proposing new ideas, with buildings designed with a greater awareness of the relationship between itself and learning.

\subsection{Experiences and Points of View}

In line with these premises, Track $\mathrm{C} 1$ explores the relationship between architecture and education through good practices and pilot projects. The session dealt with the importance of the quality of space in the education experience and it investigated the interactions between a school's architecture and its urban context, with a 
view to finding new opportunities for mutual exchange and enhancement. Different perspectives were collected during the symposium, as outlined in the following paragraphs.

Rubino considers architecture's role in influencing the learning process, or whether architecture needs to adapt to new teaching methods, building on the rich literature and a series of good practices that demonstrate possible interactions between pedagogy and architecture. Relevant to this point is the recent development in European schools that makes use of hybrid spaces (e.g., staircases, open air gardens) as new learning areas. Similarly, Ferrari et al. ask whether school architecture should reflect different teaching models, by providing multifaceted and adaptable spaces that are modifiable for future needs. The focus is the classroom of the future, for which a group of ten architects was asked to make a contribution. Yet, some pioneering examples of school architecture from the past already displayed similar design attempts. They focused on children as the protagonists of the space, using architecture to enhance their first community experience and their creative skills. Cabras et al. explore the link between space and dynamic perception and connect it to the idea of "affordance" where, by experiencing innovative spaces, children can learn new concepts and ideas. The reverse approach is also true and the school space designed by the authors and proposed in the paper is shaped around the psychosomatic perception of the child, thus features a continuous architectural space where the experience of learning takes place through action and movement. For example, the school's "water room", which recycles the historic building's old water tank, has an important pedagogic function, as it draws children's attention to sustainability and environmental issues. In Faiferri et al. a stronger and more reciprocal relationship between the school building and the city is aimed for, as an essential part of the future of education. Projects developed within the framework of the International Scientific School's "Innovative Learning Spaces", held yearly in Alghero, explore the possibilities of an increased connection between school and urban structure. In Mondaini et al., school design is directly associated with the need to respond to the current technological evolution of communication processes and educational practices. The classroom is no longer suited to teaching activities and its boundaries must open to a more adaptable and flexible concept of educational environment. Some northern European references and some of the authors' design experiences show innovative design approaches trying to break the constrictions of school architecture of the past and propose transparent, fluid learning environments that establish a continuity with the outdoor space. Finally, D'Annuntiis et al. report the experience of a university course held by the authors in collaboration with UNICEF, one of the first of its kind in Italy. Particular care was taken to understand children's rights to education and their need to acquire the skills for new tools and technologies. Also, architecture students were asked to elaborate on good practices in school architecture and to test a participatory planning process involving children in Grottammare and aimed at co-creating more suitable learning and living spaces in the town. 


\section{Conclusions}

The contributions in this track present different solutions with different origins. Some of them focus on the necessary link between the architectural design process, the teaching methods, and the pedagogic needs: some methods work effectively when space is designed to support the learning experience. For example, flexible areas with specific furniture can boost new visions and creations. By adhering to the concept of affordance and respecting the rights of young people, different spaces can stimulate new meanings in students and suggest new learning paths to teachers. Also, as social stakeholders, schools are part of the city and should be connected to important amenities, making them more accessible to the neighborhood.

The track highlighted that different approaches to space and pedagogy, and new design processes already exist in academic research and have been experimented in several schools. So what could be next?

On the academic side, we noted an important connection between the two sciences involved in this process: architecture and pedagogy should work more closely together to provide frameworks and guidelines to governing institutions. Secondly, it is important to communicate the pedagogic role of space to the public stakeholders that are responsible for school buildings. At this time of pandemic, it is especially important for all stakeholders to collaborate on creating solutions that combine safety, wellbeing and new methods. Furthermore, it is important to provide school models that include new pedagogic ideas and innovative school environments. That is how a new design approach can be implemented. One possible model is the one created by Indire (Tosi 2019), based on five different kinds of spaces plus one (the classroom), which offers both a flexible framework that can be studied and adapted to different schools, and a tool for teachers for designing new activities for a new space.

In conclusion, a closer collaboration between architecture and pedagogy is needed to help school and politics reimagine school buildings and their internal space. It is also important to keep an open mind to experimental and innovative school initiatives, and define models arising in different contexts as opportunities for upgrading the learning environment and the overall educational experience.

\section{References}

Attia, S., Weyland, B.: Body and Mind: How the Corporeal Can Serve as a Contact Point Between Architecture and Pedagogy. FAMagazine, Parma (2016)

Bosch, R.: Designing for a Better World Starts at School. Saxo Publish, Copenhagen (2018)

Cabras, L., Pusceddu, F.: UP school: motion, perception, learning. In: Scaradozzi, D., Guasti, L., Di Stasio M., Miotti, B., Monteriù, A., Blikstein, P. (eds.) Makers at School, Educational Robotics and Innovative Learning Environments-FabLearn Italy 2019, vol. 1. Springer, Heidelberg (2020)

D’Annuntiis, M., Cipolletti, S.: Child friendly architectures. Design spaces for children and adolescents. In: Scaradozzi, D. et al. (op.cit.)

Edwards, C., Gandini, L., Forman, G.: The hundred languages of children: The Reggio Emilia experience in transformation, 3rd edn. Prager Press, Santa Barbara, CA (2012) 
Faiferri, M., Bartocci, S.: Landscapes of knowledge and innovative learning experiences. In: Scaradozzi, D. et al. (op.cit.)

Ferrari, M., Tinazzi, C.: School space ideas for the future. In: Scaradozzi, D. et al. (op.cit.)

Ingold, T.: The Perception of the Environment. Routledge, London (2000)

MIUR. (2012). Indicazioni Nazionali per il Curricolo, Roma, Le Monnier

Mondaini, G., Rosciani, M.: Adaptive environments. New spaces for learning. In: Scaradozzi, D. et al. (op.cit.)

Rubino, A.C.: Multipurpose learning environments for a flexible didactic. In: Scaradozzi, D. et al. (op.cit.)

Tosi, L. (Ed.).: Fare didattica in spazi flessibili: progettare, organizzare e utilizzare gli ambienti di apprendimento a scuola. Giunti Scuola (2019)

Open Access This chapter is licensed under the terms of the Creative Commons Attribution 4.0 International License (http://creativecommons.org/licenses/by/4.0/), which permits use, sharing, adaptation, distribution and reproduction in any medium or format, as long as you give appropriate credit to the original author(s) and the source, provide a link to the Creative Commons license and indicate if changes were made.

The images or other third party material in this chapter are included in the chapter's Creative Commons license, unless indicated otherwise in a credit line to the material. If material is not included in the chapter's Creative Commons license and your intended use is not permitted by statutory regulation or exceeds the permitted use, you will need to obtain permission directly from the copyright holder. 